\title{
Involvement of schoolchildren of Buryatia and the TransbaikalTerritory in scientific activities
}

\author{
Anna Viktorovna Shapieva ${ }^{11}$, Evgenii Vladimirovich $\mathrm{Nolev}^{2}$, and Oleg Sergeevich Ochirov ${ }^{3}$ \\ ${ }^{1}$ Transbaikal State University, Department of Sociology, Chita, Russia \\ ${ }^{2}$ Institute for Mongolian, Buddhist and Tibetan studies, Siberian Branch of the Russian Academy of \\ Sciences, Department of History and Culture of Central Asia, Ulan-Ude, Russia \\ ${ }^{3}$ Baikal institute of Nature Management, Siberian branch of Russian academy of science, Ulan-Ude, \\ Russia
}

\begin{abstract}
The study is aimed at determining the factors of motivation for research activities among schoolchildren of the Republic of Buryatia and the TransbaikalTerritory. The employed sociological approach in the study made it possible to analyze the cognitive and social needs of schoolchildren in research activity, to assess the influence and role of social factors (conditions of social life of students) in the formation and content of motives for research activities of schoolchildren, and also to distinguish schoolchildren's expectations and opportunities needed to implement research activities. When organizing research work with students, developing a scientific infrastructure in education, the issues of student motivation acquire particular relevance. Taking into account the high level of the influence of a scientist's image on the choice of student science-oriented specialization, strengthening the positive image of a scientist in society becomes an urgent task. Since teachers are the key figures in attracting schoolchildren to research, it is necessary to give priority attention to the methodical and methodological training of teachers in the field of research activities, along with providing scientific infrastructure for schoolchildren. The experience of implementation of scientific and educational projects "Scientific Accelerator" in Buryatia and the Science Festival "NAUKA 0+" in the TransbaikalTerritory showed that the competencies and methodological approaches in the field of research activities that students master within the framework of projects cannot always be developed inthe further educational process. At the same time, an important factor in motivating students is meeting with scientists who act as carriers of advanced academic knowledge and also form a positive image of the profession among students. The results of the study can be applied in the development of standards and rules for the implementation of educational activities.
\end{abstract}

Keywords:science, education, research activities, motivation

\section{Introduction}

${ }^{1}$ Corresponding author:shapievaav@mail.ru 
The scientific potential of young people in the modern world is one of the key factors for the competitive development of the state, determined by the growth of science-intensive technologies, increased digitalization, and demanding requirements for the competence training of specialists [1]. This standpoint emphasizes the importance and relevance of scientific activity, which in modern conditions "replaces traditional social functions of ideology and prestige with new ones, such as scientific leadership, collective scientific creativity, an active position of a person of science"[2]. On the one hand, this led to the increased attention of governments of different countries to the problem of developing scientific and innovative potential of young people, on the other hand, to the introduction of inquiry-based learning [3]. It focused the interest of researchers on the study of cognitive abilities of children and adolescents, integration of science and education, measures and mechanisms for involving schoolchildren in research activities and innovative creativity [4-8].

The principle of integrating science and education is referred to in Article 11 of the Federal Law "On Science and State Scientific and Technical Policy"[9], creating conditions for the participation of young people in scientific activities is recognized as one of the priority goals of youth policy in the Russian Federation [10].

Along with the task of forming an integrated system of training and professional growth of scientific and scientific-pedagogical personnel indicated in the Decree of the President of the Russian Federation "On national goals and strategic tasks of development of the Russian Federation for the period up to 2024"[11], there is quantitative stability with a slow decrease in the number of young researchers, especially in the regions of the Far East [12].

The above actualizes the need to study one of the components of the youth preparedness for research activities, namely, the motivational component.

\section{$2 \quad$ Methods}

The employment of sociological approach allows analyzing the cognitive and social needs of schoolchildren in research activity, to assess the influence and role of social factors (conditions of social life of students) in the formation and content of the motives for research activities of schoolchildren, necessary for the implementation of research activities; to describe the expectations and opportunities of schoolchildren.

In 2019, on the grounds of the Regional Public Organization "Council of Young Scientists of the Republic of Buryatia" and the Independent Scientific and Analytical Sociological Service of the Transbaikal State University, an empirical sociological study "Research motivation of schoolchildren" was carried out. Its goal is to study the factors that promote or hinder the attraction and consolidation of the younger generation (schoolchildren) to research activities, as an integral part of the reproduction of the human resource system in the sphere of science and innovation.

The study was carried out by the method of a sample survey of schoolchildren in grades 6-11 according to a formalized questionnaire in urban and municipal districts of Buryatia and Transbaikalia. The geography of the study is represented by schools of municipal and urban districts of the Republic of Buryatia, participants in the project "Scientific Accelerator: Involving Youth in Research Activities"[13], within which a phase-by-phase selection of schools with the greatest research potential of schoolchildren was carried out. In Transbaikalia, municipal and urban districts were selected according to the same principle, taking into account the analysis of the activity and effectiveness of schoolchildren research activities. The choice of such a selection principle is quite objective, as motivation of schoolchildren for research activities in educational institutions where the system of attracting students to research work is poorly developed, is non-representational, and it a priori will give false results. 
The sample is representative, multi-stage: the first stage is stratified, 2 new subjects of the Far Eastern Federal District, as territories of special state attention, the Republic of Buryatia and the TransbaikalTerritory. The second is quota-based. The sample structure is determined by the following criteria: full-time education in a secondary general education school; interest in research activities (participation in a research project implemented in the region), Republic of Buryatia $n=350$, TransbaikalTerritory $n=350$ ). Among the respondents, $41 \%$ boys and $59 \%$ girls are students of 15 secondary schools in Buryatia and $47 \%$ boys and 53\% girls are students of 26 secondary schools and gymnasiums of Transbaikalia, respectively, which corresponds to the ratio of boys and girls studying full-time in secondary schools in those regions.

\section{$3 \quad$ Results}

Among the respondents, slightly less than half of the respondents have experience in research activities (Table 1).

Table 1.Involvement in the research activities.

\begin{tabular}{|l|c|c|}
\hline \multirow{2}{*}{ Region } & \multicolumn{2}{|c|}{ Have you been engaged in research activities? } \\
\cline { 2 - 3 } & Yes & No \\
\hline The Republic of Buryatia & $46 \%$ & $54 \%$ \\
\hline TransbaikalTerritory & $47 \%$ & $53 \%$ \\
\hline
\end{tabular}

About $34 \%$ of respondents in Buryatia and 30\% in Transbaikalia express a persistent and conscious desire to engage in scientific activities. $14 \%$ of schoolchildren in grades $6-8$ talk about their possible participation in research activities in high school or after finishing school, because they see opportunity in such activities. It is natural that among those who are engaged in research and activities, the absolute majority are happy and satisfied with this type of activity. $14 / 9 \%$ of respondents (Buryatia/Transbaikalia) are not ready to engage in research activities. According to the quota-based criterion, the respondents previously indicated their interest in science, which is why they became participants in scientific projects. We assume that schoolchildren became participants in research (and projects) due to other reasons not related to research interest, for example, based on high academic performance in the disciplines of the school course. Note that for $4 / 3 \%$ of schoolchildren (Buryatia/Transbaikalia), scientific activity is interesting as a leisure activity characterized by freedom of thought, scientific inquiry and creativity.

The most common types of research work among schoolchildren are: personal participation in scientific and practical conferences, seminars, schools of sciences, etc. (Table 2).

Table 2. Types of research activities.

\begin{tabular}{|l|c|c|}
\hline \multicolumn{1}{|c|}{ Answer options } & $\begin{array}{c}\text { The Republic } \\
\text { of Buryatia }\end{array}$ & TransbaikalTerritory \\
\hline Research and/or artistic and creative works competition & $33 \%$ & $29 \%$ \\
\hline Scientific and practical conference & $37 \%$ & $38 \%$ \\
\hline Subject Olympiad & $55 \%$ & $53 \%$ \\
\hline Exhibition of research and/or artistic and creative works & $12 \%$ & $24 \%$ \\
\hline Work on a grant, project & $9 \%$ & $5 \%$ \\
\hline Writing an article, report & $14 \%$ & $18 \%$ \\
\hline Educational forum, school, seminar, etc. & $7 \%$ & $9 \%$ \\
\hline Other (specify) & $4 \%$ & $5 \%$ \\
\hline None & $4 \%$ & $4 \%$ \\
\hline No answer & $0 \%$ & $0 \%$ \\
\hline
\end{tabular}


About $63 / 54 \%$ of respondents (Republic of Buryatia/TransbaikalTerritory) stated the results of their research activities. The first steps of students towards scientific research are based on a personal attitude towards the science subjects. The most interesting for schoolchildren of the Republic of Buryatia were natural sciences and mathematics (43\%) and socio-economic $(33 \%)$ areas of research. Commonly, under modern conditions, technical (including engineering) and philological fields are less popular among schoolchildren ( $12 \%$ each, respectively).

The most accessible methods of research activities are work with scientific literature (45/39\%, Buryatia/Transbaikalia), experiments and tests within the framework of training sessions $(36 / 41 \%)$. However, the most attractive and interesting for schoolchildren are "field" methods of scientific activity. It has been noted that teachers in their work also give preference to traditional methods of involving students in research.

\section{Discussion}

In view of the various sources of schoolchildren activity (personal, external, internal sources), research activities should be understood as multi-motivated.

Sources of private origin determine the aspiration of a student with research experience to cognition, creation of new knowledge $(50 / 49 \%)$ and self-realization in research work $(46 / 48 \%)$. Schoolchildren with no research experience are often attracted by material benefits (marks, scholarships, extra points $-74 / 74 \%$ ) and the idea of research as a kind of tool for gaining recognition and prestige $(83 / 83 \%)$. (Republic of Buryatia/TransbaikalTerritory, Figure 1). There is a difference in the motives of schoolchildren, depending on whether they have research experience.

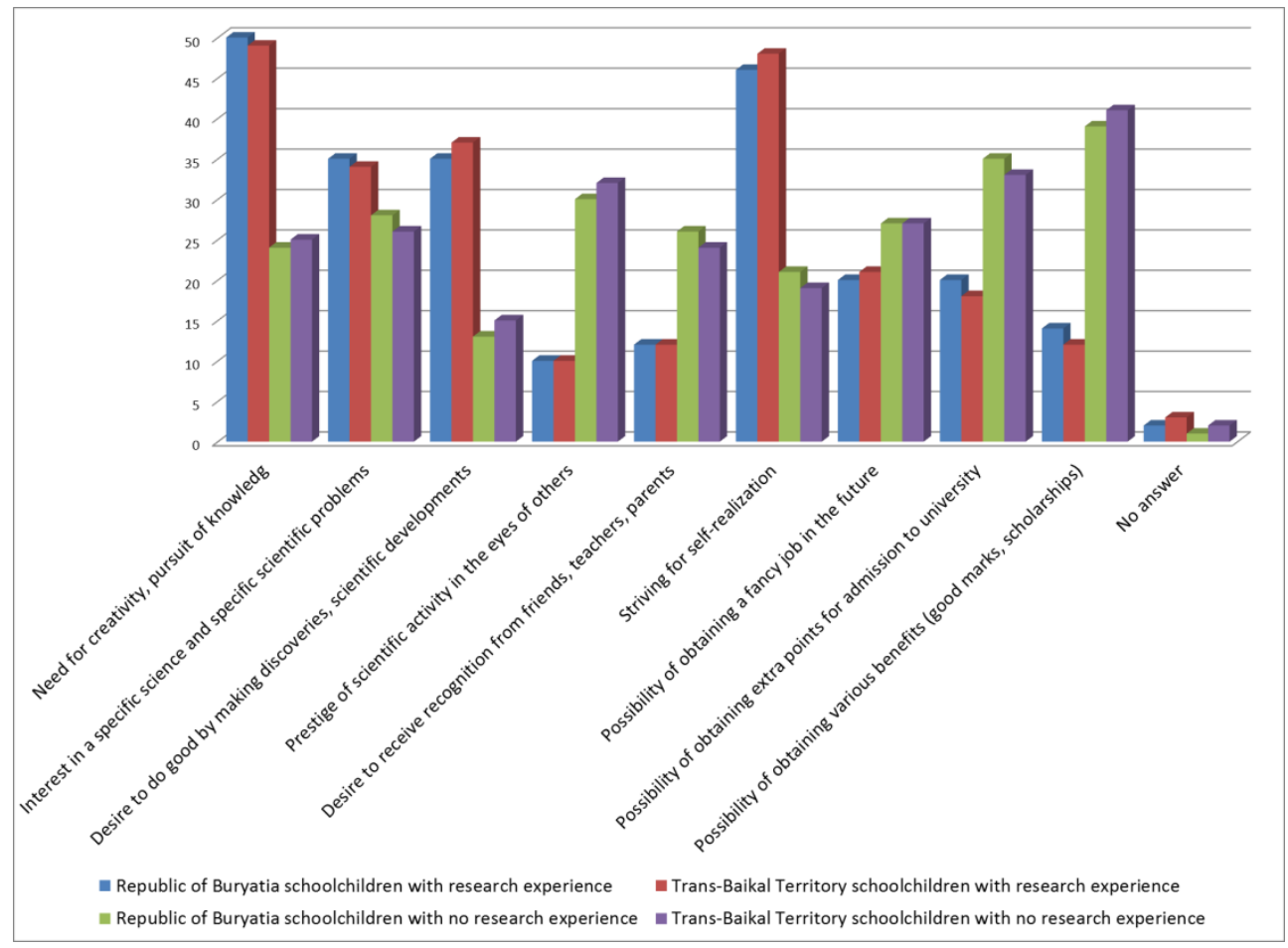

Fig.1. Reasons of "doing science" for different respondents. 
The way society perceives "representatives of science" affects the reproduction of the human scientific potential in this area, as well as the perception of a scientist affects the involvement of schoolchildren in research, which is characterized by formal acceptance and assimilation of specific role expectations [14]. The top answers indicate the qualities of a scientist that a person achieves independently, and a small number of answers determine the qualities of a scientist of natural essence - genius (6\%), persistent (4\%), diligent $(0.8 \%)$, etc. The exception is the quality "creative" highlighted by the respondents. It should be noted that internal sources of motivation for research work presuppose that interest in the object under study is maintained even after the need itself is realized.

Schoolchildren associate research activities with smart people (51/53\%), high qualification $(42 / 39 \%)$, the ability of self-realization $(31 / 30 \%)$ and making a career (32/34\%). Schoolchildren do not believe that science allows gaining power. For $27 / 25 \%$ (Buryatia/Transbaikalia), scientific activity is associated with an opportunity to earn money (Figure 2).

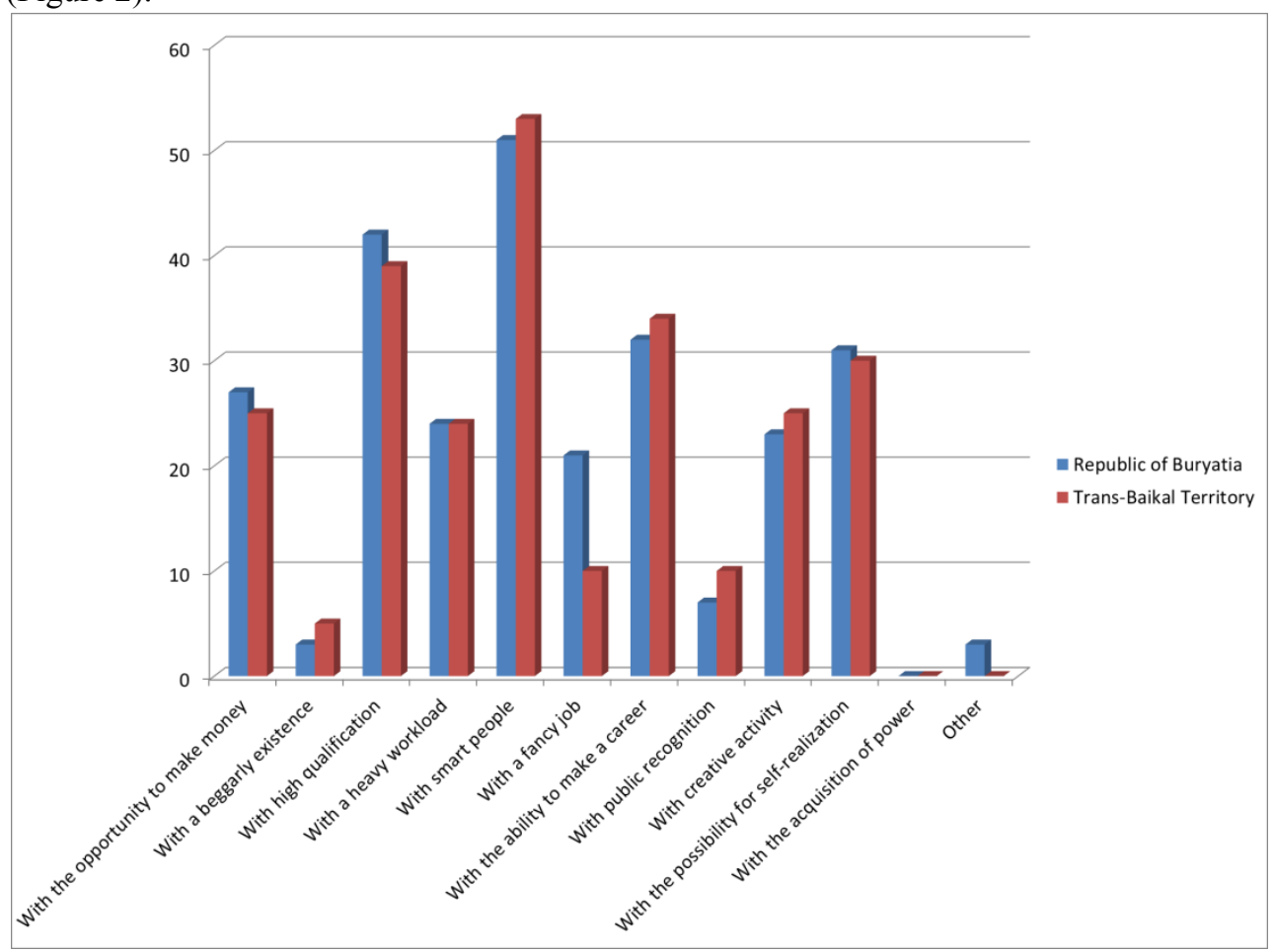

Fig. 2. Research activities associations.

External sources of motivation are correlated with the environment for the implementation of scientific research and the process of scientific work, with the response of society to scientific results that schoolchildren expect. The majority of respondents in each region answered that the positive opinion of people around them boosts their desire to conduct research, 64/63\% (Buryatia/Transbaikal), i.e. the dominant motive is to get an external assessment of one's activities.

According to the respondents, teachers are the main motivating figure for research work (43/54\%). More than $30 \%$ of schoolchildren (in two regions) developed a desire to engage in science "at home voluntarily as they wish", which demonstrates a genuine interest in science. 


\section{Conclusion}

The adoption of the new Federal Law re-actualizes questions regarding the form of organization, subjects and content of educational activities, which is directly related to the involvement of schoolchildren in research activities [15]. At present, elements of scientific infrastructure in education are actively developing in Buryatia and the TransbaikalTerritory. At the same time, as the research has shown, the issues of student motivation come to the forefront. An important factor in motivating students is meeting with scientists who act as carriers of advanced academic knowledge and form a positive image of the scientific profession among students, which stimulates the task of strengthening the positive image of a scientist in society. Since teachers are the key figures in attracting schoolchildren to research, it is necessary to give priority attention, to the methodical and methodological training of teachers in the field of organizing research activities, along with the creation of a scientific infrastructure.

The article was prepared within the framework of a state assignment (project "Historical space of the Mongolian world: archaeological cultures, societies and states", No. 121031000241-1).

\section{References}

1. V.F.Potudanskaya, N.V.Borovskikh, E.A. Kipervar, Rus. J. Labor Econ.5(3), 735(2018). https://doi.org/10.18334/et.5.3.39252

2. A.I.Ermilin, E.V.Ermilina, E.I.Perfilieva,Metodologiyanauchnoideyatelnostishkolnikov[Methodology of Scientific Activity ofSchoolchildren](Nizhny Novgorod, 2018)

3. H.Tang, et al., SAGE Open, 10(2)(2020). https://doi.org/10.1177/2158244020932511

4. C.D.Hondzel, M.S.Gulliksen, SAGE Open, 5(4)(2015). https://doi.org/10.1177/2158244015611448

5. A.Mohanty, S.P. Das,SAGE Open, 5(1)(2015).https://doi.org/10.1177/2158244014567924

6. S.A. Yun-Hai, Heralds of Buryat State Univ.7, 78-85(2017)

7. Y.Gumala, et al., J. Elem. Edu.4(1), 74-82(2020)

8. M.G. Tsyrenova (ed.), Uchebno-issledovatelskaya deyatelnost v sisteme obshchego, dopolnitelnogo i professionalnogo obrazovaniya: materialy vserossiiskoi nauchno-prakticheskoi konferentsii (g. Ulan-Ude, 5-6 noyabrya 2020 g.) [Educational and Research Activities in the System of General, Additional and Vocational Education: Materials of the All-Russian Scientific and Practical Conference (Ulan-Ude, November 5-6, 2020)](Publishing House ofBuryat State University, Ulan-Ude, 2021)

9. Federalnyizakonot 23 avgusta 1996 g. № 127-FZ “O naukeigosudarstvennoinauchno-tekhnicheskoipolitike" [Federal Law of August 23, 1996, No. 127-FZ“'On Science and State Scientific and Technical Policy”].Accessed on: July 23, 2021. [Online]. Available: http://www.consultant.ru/document/cons_doc_LAW_11507/

10. Federalnyizakonot 30 dekabrya 2020 g. № 489-FZ "O molodezhnoipolitike v RossiiskoiFederatsii" [Federal Law of December 30, 2020, No. 489-FZ "On Youth Policy in the Russian Federation"].Accessed on: July 23, 2021. [Online]. Available: http://www.consultant.ru/document/cons_doc_LAW_372649/ 
11. UkazPrezidentaRossiiskoiFederatsiiot 07.05.2018 g. № 204 “O natsionalnykhtselyakhistrategicheskikhzadachakhrazvitiyaRossiiskoiFederatsiina period do 2024 goda" [Decree of the President of the Russian Federation of May 7, 2018, No. 204 "On National Goals and Strategic Tasks of Development of the Russian Federation for the Period up to 2024"].Accessed on: July 23, 2021. [Online]. Available:http://www.kremlin.ru/acts/bank/43027

12. S.V. Bredikhin, V.V. Vlasova, M.A. Gershman, etal., Nauchno-tekhnologicheskayapolitikaRossii v usloviyakhpostpandemii:

poisknovykhreshenii [Scientific and technological policy of Russia in the post-pandemic conditions: search for new solutions], inL.M. Goghberg (ed.),Proc. XXII Apr. International scientific conference. On problems of economic and social Development, April 13-30, Moscow (Publ. house HSE, Moscow, 2021)

13. E.V.Nolev, O.S. Ochirov,O merakh i napravleniyakh podderzhki deyatelnosti molodykh uchenykh $v$ Respublike Buryatiya[On Measures andAreas of Support ofActivity ofYoungScientists in the Republic of Buryatia], inSocial and Political Challenges ofModernization in the $21^{\text {st }}$ century. Collection of Scientific Articles,132-135 (Ulan-Ude, 2018)

14. C.L.Walker, B.M.Shore, SAGE Open,5(4)(2015). https://doi.org/10.1177/2158244015607584

15. FederalnyiZakonot 5 aprelya 2021 g. № 85-FZ “O vneseniiizmenenii v Federalnyizakon "obobrazovanii v RossiiskoiFederatsii” [Federal Law of April 5, 2021, No. 85-FZ "On Amendments to the Federal Law On Education in the Russian Federation"].Accessed on: July 23, 2021. [Online]. Available:http://www.consultant.ru/document/cons_doc_LAW_381385/ 